\title{
Molecular Basis of Hypoxanthine-Guanine Phosphoribosyltransferase Deficiency in Ten Subjects Determined by Direct Sequencing of Amplified Transcripts
}

\author{
Beverly L. Davidson," Susan A. Tarlé," Thomas D. Palella," and William N. Kelley** \\ *Department of Internal Medicine, the Rackham Arthritis Research Unit, the University of Michigan Multipurpose Arthritis Center, \\ and ${ }^{\ddagger}$ Department of Biological Chemistry, the University of Michigan, Ann Arbor, Michigan 48109
}

\begin{abstract}
Hypoxanthine-guanine phosphoribosyltransferase (HPRT) deficiency is an inborn error of purine metabolism. Mutant HPRT gene sequences from patients deficient in enzyme activity have previously been characterized by cDNA cloning or amino acid sequencing techniques. The presence of HPRTspecific mRNA in nearly all deficient subjects, as well as the small size of the HPRT mRNA (1,400 bp), make the polymerase chain reaction (PCR) an alternative for the identification of mutations at this locus. In this report we use the PCR to identify previously undetermined mutations in HPRT mRNA from B lymphoblasts derived from 10 deficient individuals. Six of these variants contain single point mutations, three contain deletions, and one contains a single nucleotide insertion. Several of these mutations map near previously identified HPRT variants, and are located in evolutionarily conserved regions of the molecule.
\end{abstract}

\section{Introduction}

Hypoxanthine-guanine phosphoribosyltransferase (HPRT) ${ }^{1}$ deficiency is a disorder of purine metabolism responsible for two distinct clinical syndromes. Complete deficiency of HPRT causes the Lesch-Nyhan syndrome, which is characterized by hyperuricemia, hyperuricaciduria, and severe neurologic dysfunction consisting of hyperreflexia, choreathetosis, mental retardation, and self-mutilation $(1,2)$. Patients with partial deficiency have severe gout and uric acid nephrolithiasis, but are usually spared neurologic dysfunction (3).

Early reports of HPRT deficiency demonstrated heterogeneity of kinetic and electrophoretic properties of the protein

Address reprint requests to Dr. Thomas D. Palella, Department of Internal Medicine, University of Michigan, $1150 \mathrm{~W}$. Medical Center Drive, 5520 Medical Science Research Building I, Ann Arbor, MI 48109.

Received for publication 31 October 1988 and in revised form 27 March 1989.

1. Abbreviations used in this paper: $\mathrm{dNTP}$, deoxynucleoside triphosphate; HPRT, hypoxanthine-guanine phosphoribosyltransferase; PCR, polymerase chain reaction; PRPP, 5-phosphoribosyl-1-pyrophosphate.

J. Clin. Invest.

(c) The American Society for Clinical Investigation, Inc. 0021-9738/89/07/0342/05 \$2.00

Volume 84, July 1989, 342-346
$(4,5)$. The original hypothesis proposed to explain these observations was that different, independent mutations occurred in the structural gene (6). Subsequent molecular studies confirmed this observation $(7,8)$. More recently, amino acid sequencing and cDNA cloning have been used to identify the molecular basis of HPRT deficiency in 11 subjects (9-19).

Study of these naturally occurring mutants has revealed the structural and catalytic importance of certain regions of the molecule. However, the techniques used to identify these mutations are laborious, and have been dependent on sufficient residual levels of HPRT protein for amino acid sequence analysis or HPRT-specific mRNA for cDNA cloning.

In this report, we have used the polymerase chain reaction (PCR) to amplify HPRT-specific sequences from total RNA isolated from B lymphoblasts derived from 10 patients (20). Three of these subjects have partial deficiency and seven have Lesch-Nyhan syndrome. Direct sequencing of the amplified products allowed rapid identification of mutant gene sequences. This technique is applicable to the identification of mutations and carrier status for any inborn error of metabolism for which normal DNA sequence information is available. From these data, important structure-function relationships can be inferred.

\section{Methods}

Cell lines. The methods used to establish and maintain B lymphoblastoid cell lines have been described (21). Cell lines J.M., M.S., and W.B. were derived from patients with partial HPRT deficiency. W.B. is the maternal uncle of M.S. Cell lines E.C., B.S., D.G., D.M., H.D., D.A., and K.M. were derived from unrelated patients with Lesch-Nyhan syndrome. Cell line GM558 is derived from a normal male (Human Mutant Cell Repository, Camden, NJ).

PCR primers. The two PCR primers that consistently gave us a high level of amplification were HT5' and HT3'. HT5' hybridizes to nucleotides -118 to -101 of the antisense strand of the HPRT transcript, while HT3' anneals to nucleotides 727-759 of the sense strand. The sequences of HT5' and HT3' are GCGAACCTCTCGGCTTTC and AAGCTCTACTAAGCAGATGGCCACAGAACTAGA, respectively. Primer $\mathrm{HT}^{\prime}$ is the reverse complement of the sense strand of HPRT, with nucleotide 759 listed first and nucleotide 727 given last.

RNA isolation and in vitro amplification. RNA was isolated from the above cell lines using guanidium isothiocyanate (22). Total cellular RNA (1 $\mu \mathrm{g})$ was primed with oligo $\mathrm{d}(\mathrm{T})_{12-17}$ (23; Pharmacia Fine Chemicals, Piscataway, NJ) and reverse transcribed in a total reaction volume of $50 \mu \mathrm{l}$. A portion of this reaction was diluted 1:5 in a buffer containing $25 \mathrm{mM} \mathrm{KCl}, 0.2 \%$ gelatin, $40 \mu \mathrm{M}$ deoxynucleoside triphosphate (dNTP), 1 U of Taq DNA polymerase (Perkin-Elmer Cetus, Norwalk, CT), and $1 \mu \mathrm{g}$ PCR primers (Figs. 1 and 2). The reaction mixture was overlayed with mineral oil, and DNA amplification was performed in a Thermocycler (Perkin-Elmer Cetus). 30 cycles of am- 
A

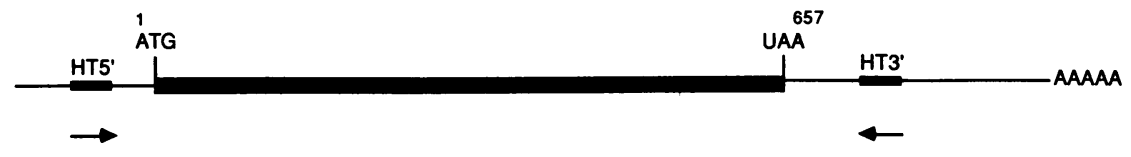

Figure 1. Strategy for PCR amplification and sequencing of amplified products of HPRT variants. $(A)$ The PCR primers HT5' and HT3' were used to amplify HPRT sequences from oligo $d(T)$ primed DNA:RNA hybrids synthesized using avian myeloblastosis virus reverse transcriptase. The relative priming sites (stipled boxes) and direction of extension for HT5' and HT3' (arrows) are indicated. The base number for the A of the ATG start codon and the terminal $A$ of the UAA stop codon are indicated. $(B)$ For direct sequencing of amplified products, phosphorylated primers specific for HPRT (1-8) were annealed and extended as described in Methods. The direction of extension is indicated by arrows. The extent of the overlapping sequence is represented approximately by the overlap of the arrows.

plification were done with each cycle consisting of $94^{\circ} \mathrm{C}, 1 \mathrm{~min}, 55^{\circ} \mathrm{C}$, $1 \mathrm{~min}$, and $72^{\circ} \mathrm{C}, 3 \mathrm{~min}$. Each cell line was reverse transcribed and amplified a minimum of three times from independent RNA isolates to insure the authenticity of mutations found upon sequencing of amplified transcripts.

Sequencing. Sequencing of the amplified HPRT transcripts was done directly without cloning using dideoxynucleotide chain termination (24). All of the coding sequence of both strands was sequenced using eight HPRT-specific oligodeoxynucleotides that hybridize to HPRT coding sequence internal to the PCR primers. The primers were phosphorylated with $\left[\gamma-{ }^{32} \mathrm{P}\right] \mathrm{dATP}(6,000 \mathrm{Ci} / \mathrm{mmol})$ and T4 polynucleotide kinase and used in eight separate sets of sequencing reactions $(13,25)$. The regions to which these primers anneal, and the extent of

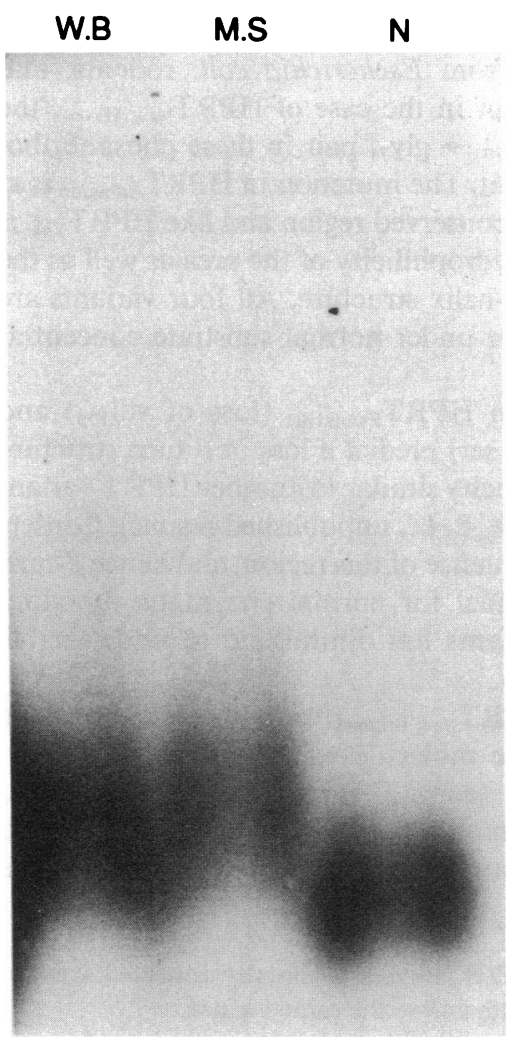

Figure 2. Activity stain of HPRT from W.B. and M.S. (HPRT Artington$_{\text {). Approx- }}$ imately $500 \mu \mathrm{g}$ of protein from membranefree lymphoblast extracts isolated from cell lines W.B. and M.S., and $5 \mu \mathrm{g}$ of protein from a normal control (GM558) were electrophoresed through a $6 \%$ nondenaturing polyacrylamide gel and stained for HPRT activity (see Methods).

The migration of HPRT $_{\text {Arlington }}$ from subjects W.B. and M.S. is less anodal than normal, consistent with the aspartic acid to valine substitution at amino acid 80 . overlap of the sequence generated, are depicted in Fig. 2. Direct sequencing was done using a modification of the procedures described by Engelke et al. (26). $2 \mu \mathrm{l}$ amplified DNA was combined with $4 \mu \mathrm{l}$ of ddNTP mixture (600 $\mu \mathrm{m}$ each dNTP and $40 \mu \mathrm{m}$ of the appropriate dideoxynucleotide), $4 \mu \mathrm{l}$ of $10 \times$ buffer ( $1 \times$ buffer is $20 \mathrm{mM}$ Hepes, $\mathrm{pH}$ $7.5,50 \mathrm{mM} \mathrm{NaCl}$, and $10 \mathrm{mM} \mathrm{MgCl}$ ), and $100,000 \mathrm{cpm}$ of one of the ${ }^{32} \mathrm{P}$-labeled HPRT-specific primers. The samples, in a total reaction vol of $40 \mu \mathrm{l}$, were denatured for $3 \mathrm{~min}$ at $95^{\circ} \mathrm{C}$, then placed at $42^{\circ} \mathrm{C}$ for 5 min to allow the primer to anneal. This was followed by the addition of $1 \mathrm{U}$ of Sequenase (U.S. Biochemical Corp., Cleveland, $\mathrm{OH}$ ) and a 5-min polymerization step at $42^{\circ} \mathrm{C}$. The denature/anneal/polymerize cycle was repeated twice. A solution of proteinase $K(1 \mathrm{mg} / \mathrm{ml})$, SDS (2\%), and EDTA (100 mM, pH 8.0) was added, and the reaction mixture was incubated at $50^{\circ} \mathrm{C}$ for $30 \mathrm{~min}$. The samples were precipitated on dry ice after the addition of EDTA, $\mathrm{NaCl}$, glycogen (final concentrations $7 \mathrm{mM}, 100 \mathrm{mM}$, and $0.02 \mathrm{mg} / \mathrm{ml}$, respectively), and 2 vol of ethanol, and resuspended in $8 \mu$ l of dideoxy sequencing dye ( $98 \%$ formamide, $10 \mathrm{mM}$ EDTA, and $0.1 \%$ xylene cyanol FF and bromophenol blue). An aliquot of each reaction $(4 \mu \mathrm{l})$ was electrophoresed at constant wattage $(60 \mathrm{~W})$ for either 1.5 or $3 \mathrm{~h}$ through $4 \%$ polyacrylamide gels containing $8 \mathrm{M}$ urea. The gels were fixed in 5\% methanol/ $5 \%$ acetic acid for $10 \mathrm{~min}$, transferred to $3 \mathrm{MM}$ paper (Whatman Laboratory Products Inc., Clifton, $\mathrm{NJ}$ ), dried under vacuum at $80^{\circ} \mathrm{C}$, and autoradiographed.

Enzyme analyses. HPRT enzyme activity was measured in membrane-free lysates as previously described (27). The final concentrations of hypoxanthine, 5-phosphoribosyl-1-pyrophosphate (PRPP), $\mathrm{MgCl}_{2}$, and Tris- $\mathrm{HCl}$ are $50 \mu \mathrm{M}, 200 \mu \mathrm{M}, 4.2 \mathrm{mM}$, and $50 \mathrm{mM}$, respectively. Nondenaturing PAGE was performed in $6 \%$ polyacrylamide gels using $500 \mu \mathrm{g}$ of protein from subjects W.B., M.S., K.M., and D.G. $5 \mu \mathrm{g}$ of total protein from GM558 cell lysate was used as a normal control. After electrophoresis the gels were overlayed with a reaction mixture containing $1 \mathrm{mM}\left[8-{ }^{14} \mathrm{C}\right]$ hypoxanthine $(57 \mathrm{mCi} /$ mmol), $15 \mathrm{mM}$ PRPP, $30 \mathrm{mM} \mathrm{MgCl}$, and $100 \mathrm{mM}$ Tris- $\mathrm{HCl}$, pH 7.4 . The gel was incubated at $37^{\circ} \mathrm{C}$ for $2 \mathrm{~h}$ and blotted onto polyethyleneimene cellulose (Sybron/Brinkman, Westbury, NY). The polyethyleneimene cellulose was then dried and autoradiographed (28).

Secondary structure predictions. The PEPTDIDESTRUCTURE and PLOTSTRUCTURE programs for prediction of secondary structure were from the Genetics Computer Group, Madison, WI, and have been previously described $(14,29)$.

\section{Results}

All seven cell lines derived from patients with the LeschNyhan syndrome (D.A., D.G., H.D., K.M., D.M., E.C., and 
B.S.) and two subjects with partial deficiency (W.B. and M.S.) had levels of HPRT activity $<0.1 \mathrm{nmol} / \mathrm{min}$ per $\mathrm{mg}(<0.7 \%$ of control). HPRT activity in J.M. was $0.2 \mathrm{nmol} / \mathrm{min}$ per $\mathrm{mg}$ (1.4\% of control).

Direct dideoxynucleotide sequencing of the PCR-amplified HPRT transcripts from these 10 cell lines revealed nine different mutations. RNA isolation, reverse transcription, amplification, and sequencing were repeated at least three times for each cell line. For each variant the same mutation was identified in independent amplifications, and was the sole departure from normal HPRT cDNA sequence. Thus, we conclude that these mutations are authentic and do not represent silent polymorphisms. These nine variants are designated HPRT $_{\text {Evansville }}$ (B.S.), HPRT Michigan $_{\text {(D.A.), HPRT }}$ New Haven (D.G.), HPRT Chicago $_{\text {(D.M.), }}$ HPRT $_{\text {New }}$ Briton (E.C.), HPRT $_{\text {Connersville }}$ (H.D.), HPRT Milwaukee $_{\text {(J.M.), } \text { HPRT }_{\text {Detroit }}}$

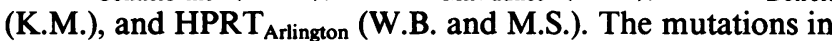
all variants except HPRT $_{\text {New Haven }}$ and HPRT $_{\text {Arlington }}$ have been confirmed by RNase mapping (Palella, T. D., unpublished observations) and are summarized in Table $\mathrm{I}$.

HPRT $_{\text {Chicago }}$ has a single nucleotide $(\mathrm{T})$ insertion at base 56 , 57 , or 58. The sequence CCTTGA becomes CCTTTGA resulting in a shift in the reading frame and the occurrence of a stop codon (UGA) at this position. The deletions in HPRT $_{\text {Evansville, }}$, HPRT $_{\text {Michigan }}$, and HRPT Connersville $_{\text {predict }}$ shortened translation products as well. In HPRT Connersville $_{\text {all of }}$ exon 8 is deleted, resulting in a change in the reading frame and the occurrence of a stop codon 15 nucleotides downstream from the exon 7:exon 9 junction. HPRT Michigan $_{1}$ is missing a codon, predicting a translation product shortened by a single amino acid. The deletion in HPRT $_{\text {Evansville }}$ predicts the replacement of those nucleotides coding for the carboxy-terminal 4 amino acids and stop codon (lys-tyr-lys-ala-stop) with a sequence that encodes an additional 28 amino acids before a stop codon is reached. The predicted translation product of HPRT $_{\text {Evansville }}$ is thus 24 amino acids longer than the normal protein.

Two of the five variants arising from point mutations predict a change in the electrophoretic properties of the enzyme, HPRT $_{\text {New }}$ Haven and HPRT Arlington. In a previous report $_{\text {. }}$ HPRT $_{\text {New Haven }}$ was shown to be an acidic variant by Western blotting (7). This is consistent with the predicted glycine to glumatic acid substitution at amino acid 70 . The predicted electrophoretic alteration in HPRT $_{\text {Arlington }}$ was confirmed using an HPRT activity assay on native protein in polyacrylamide gels (see Methods). The hypoxanthine, PRPP, and $\mathrm{MgCl}_{2}$ were $>20,75$, and 7.2 times higher than the substrate concentrations used under normal assay conditions so that any kinetic incapacity would be overcome. As shown in Fig. 2, HPRT $_{\text {Arlington }}$ is a basic variant, consistant with the aspartic acid to valine substitution.

\section{Discussion}

In the past, the basis of HPRT deficiency states has been characterized through the use of amino acid sequencing (9-12), cDNA cloning (13-19), and in one recent case, by denaturing gradient gel electrophoresis followed by amplification of the region of interest by the PCR (30). These methods are time consuming and labor intensive. More recently, the sequence of PCR-amplified transcripts from HPRT $\mathrm{H}_{\text {London }}$ and normal HPRT have been reported $(17,31)$. In both cases sequences were determined by cloning into M13 bacteriophage and sequencing. However the misincorporation rate of Taq polymerase $\left(2 \times 10^{-4} /\right.$ nucleotide per cycle [20]) necessitates sequencing many independent clones to authenticate mutations. In this report we use direct sequencing of PCR-amplified products to circumvent both of these problems in the identification of nine previously undescribed mutations.

The molecular basis of HPRT deficiency in 20 of 24 deficient subjects from our original survey population have now been defined. This includes two recently acquired variants, HPRT $_{\text {Arlington }}$ and HPRT Detroit $_{\text {. Of the remaining four HPRT }}$ variants from this population, four have undetectable levels of HPRT mRNA on Northern blot analysis, but have no gross genetic rearrangements on Southern blots. The remaining variant is currently under study. Thus, the population of 20 variants $^{2}$ consists of 13 point mutations (65\%), 5 deletions (25\%), 1 single nucleotide insertion (5\%), and 1 duplication (5\%).

Although the deletions in HPRT Connersville $_{\text {and HPRT }}$ Evansville and the insertion in HPRT Chicago $_{\text {predict grossly altered protein }}$ structures, single amino acid substitutions or small deletions may affect protein stability, kinetic capacity, or subunit interactions as well (9-18). To investigate whether those variants with point mutations or a single codon deletion may cause structural perturbations, we used the PEPTIDESTRUCTURE and PLOTSTRUCTURE programs of the Genetics Computer Group to predict structural changes (29). As summarized in Table II, changes in secondary structure are predicted in four of the six variants, while hydropathic changes are predicted in all cases. All six variants map near previously defined mutations.

The increase in hydrophilicity predicted for HPRT New Haven $_{\text {}}$ ( gly $_{70} \rightarrow \mathrm{glu}$ ) is similar to two previously defined mutants, HPRT $_{\text {Fint }}\left(\right.$ phe $_{74} \rightarrow$ leu; reference 13) and HPRT Yale $_{\left(g^{\prime} y_{71} \rightarrow\right.}$ arg; reference 16). All fall within a region of predicted $\beta$-turn and $\alpha$-helix structure that is heavily conserved among phosphoribosyltransferases from Escherichia coli, rodents, and humans (32), and, except in the case of HPRT New Haven, the initial glycine of the gly $_{70} \rightarrow$ gly $_{71}$ pair in these phosphoribosyltransferases is invariant. The mutation in HPRT $_{\text {Arlington }}$ is at the carboxyl end of this conserved region and like $\mathrm{HPRT}_{\text {Yale }}$ is predicted to affect the hydrophilicity of the area as well as the conserved $\beta$-turn and $\alpha$-helix structure. All four variants are catalytically incompetent under normal substrate concentrations.

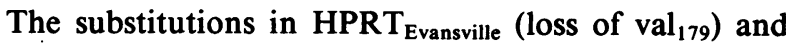
HPRT $_{\text {Milwaukee }}\left(\right.$ ala $_{161} \rightarrow$ ser) predict a loss in $\beta$-turn structure and change in hydrophilicity similar to another HPRT variant $\left(\right.$ pro $_{174} \rightarrow$ leu) (Davidson, B. L., unpublished results). Conservation of amino acid sequence of this region, and hence $\beta$-turn structure, may be essential for normal enzymatic function, since each of these variants has diminished to undetectable levels of enzyme activity.

The mutation in HPRT $_{\text {New Briton }}\left(\right.$ phe $_{199} \rightarrow$ val) is near the carboxy terminus of the molecule where two other human mutants, HPRT Kinston $\left(\operatorname{asp}_{194} \rightarrow\right.$ asn) and HPRT Ashville $_{\text {H }}$ $\left(\right.$ asp $_{201} \rightarrow$ gly), and one mouse neuroblastoma HPRT variant, NBR4 ( $\operatorname{asp}_{201} \rightarrow$ asn), have been mapped. A common feature

2. Two cell lines, G.S. and D.B., though apparently unrelated, contain the same mutation and are therefore the same variant. 
Table I. Mutations in HPRT Determined by PCR

\begin{tabular}{|c|c|c|c|}
\hline Mutant & Cell line & Nucleotide change(s) & Putative amino acid change(s) \\
\hline \multicolumn{4}{|l|}{ Insertion } \\
\hline HPRT $_{\text {Chicago }}$ & D.M. & Insertion of $T_{56}{ }^{*}$ & Translation termination at $\operatorname{asp}_{20}$ \\
\hline \multicolumn{4}{|l|}{ Deletions } \\
\hline HPRT $_{\text {Connersville }}$ & H.D. & Deletion $_{532 \rightarrow 609}$ (exon 8) & Loss of phe $178 \rightarrow$ asn $_{203}$ \\
\hline HPRT $_{\text {Michigan }}$ & D.A. & GTT $_{535 \rightarrow 537}$ deleted & Loss of $\mathrm{val}_{179}$ \\
\hline HPRT $_{\text {Evansville }}$ & B.S. & Deletion $_{643 \rightarrow 663}$ & $\begin{array}{l}\text { Loss of } \operatorname{lys}_{215} \rightarrow \text { stop codon; addition of } 24 \text { amino } \\
\text { acids (new stop site) }\end{array}$ \\
\hline \multicolumn{4}{|l|}{ Point mutations } \\
\hline HPRT $_{\text {Detroit }}$ & K.M. & $\mathrm{T}_{122} \rightarrow \mathrm{C}$ & $\mathrm{leu}_{41} \rightarrow$ pro \\
\hline HPRT $_{\text {New Haven }}$ & D.G. & $\mathrm{G}_{209} \rightarrow \mathrm{A}$ & $\mathrm{gly}_{70} \rightarrow \mathrm{glu}$ \\
\hline HPRT $_{\text {Arlington }}$ & M.S., W.B. & $A_{239} \rightarrow T$ & $\operatorname{asp}_{80} \rightarrow$ val \\
\hline HPRT $_{\text {Milwaukee }}$ & J.M. & $\mathrm{G}_{481} \rightarrow \mathrm{T}$ & ala $_{161} \rightarrow$ ser \\
\hline HPRT $_{\text {New Briton }}$ & E.C. & $\mathrm{T}_{595} \rightarrow \mathrm{G}$ & phe $_{199} \rightarrow$ val \\
\hline
\end{tabular}

* The nucleotide insertion could occur at nucleotide position 56,57 , or 58 .

of these variants is decreased substrate affinity demonstrated by large increases in the $K_{\mathrm{m}}$ 's for both PRPP and hypoxanthine $(12,18,33)$. Secondary structure analysis predicts changes in the hydrophilicity of the protein in the area surrounding these mutations. The kinetic parameters for $\mathrm{HPRT}_{\mathrm{New} \text { Briton }}$ cannot be determined due to insufficient levels of protein (7).

Although changes in secondary structure parameters are altered in most HPRT variants, correlating changes in secondary structure to the loss of enzyme function are speculative. In the absence of known three-dimensional structures for the native and mutant proteins predictive programs of this type are one way to assess the possible impact of amino acid substitutions. Estimates of accuracy using these predictive techniques range from 50 to $70 \%(34,35)$.

In summary, PCR is a rapid means for determining mutations in HPRT, allowing the identification of nine additional variants. Although mutations in HPRT are scattered throughout the molecule, clusters of mutations are now apparent. The location of these regions, in concert with secondary structure predictions, refines our understanding of structural features in HPRT that may be necessary for proper enzymatic function and stability.

Table II. Structural Changes in HPRT Variants

\begin{tabular}{lll}
\hline \multicolumn{1}{c}{ Mutant } & \multicolumn{1}{c}{$\begin{array}{c}\text { Change in } \\
\text { hydrophilicity }\end{array}$} & \multicolumn{1}{c}{$\begin{array}{c}\text { Change in secondary } \\
\text { structure }\end{array}$} \\
\hline HPRT $_{\text {Arlington }}$ & Decreased & $\begin{array}{c}\alpha \text {-Helix and random coil } \\
\text { converted to } \beta \text {-sheet }\end{array}$ \\
HPRT $_{\text {Detroit }}$ & Increased & N.P.* \\
HPRT $_{\text {Milwaukee }}$ & Increased & Loss of two $\beta$-turns \\
HPRT $_{\text {New Briton }}$ & Increased & N.P. \\
HPRT $_{\text {New Haven }}$ & Increased & N.P. \\
HPRT $_{\text {Evansville }}$ & Decreased & Loss of two $\beta$-turns
\end{tabular}

* No change predicted.

\section{Acknowledgments}

The authors wish to thank David S. Ginsburg, Howard Hughes Medical Institute, University of Michigan, for many helpful discussions. Also, the technical help of Mary Elizabeth Van Antwerp and Patricia Hoener is greatly appreciated. Much thanks also for the expert secretarial assistance of Ardith Listeman.

This work was supported by National Institutes of Health grant DK-19045 and Multipurpose Arthritis Center grant P60-AR20557. Dr. Davidson is the recipient of a fellowship from Program for Protein Structure and Design.

\section{References}

1. Seegmiller, J. E., F. M. Rosenbloom, and W. N. Kelley. 1967. Enzyme defect associated with a sex-linked human neurological disorder and excessive purine synthesis. Science (Wash. DC). 155:16821684.

2. Lesch, M., and W. L. Nyhan. 1964. A familial disorder of uric acid metabolism and central nervous system function. Am. J. Med. 36:561-570.

3. Kelley, W. N., F. M. Rosenbloom, J. F. Henderson, and J. E. Seegmiller. 1967. A specific enzyme defect in gout associated with overproduction of uric acid. Proc. Natl. Acad. Sci. USA. 57:17351739.

4. Kelley, W. N., and J. C. Meade. 1971. Studies on hypoxanthineguanine phosphoribosyltransferase in fibroblasts from patients with the Lesch-Nyhan syndrome: evidence for genetic heterogeneity. $J$. Biol. Chem. 246:2953-2958.

5. Arnold, W. J., J. C. Meade, and W. N. Kelley. 1972. Hypoxanthine-guanine phosphoribosyltransferase. Characteristics of the mutant enzyme in erythrocytes from patients with the Lesch-Nyhan syndrome. J. Clin. Invest. 51:1805-1812.

6. Haldane, J. B. S. 1935. The rate of spontaneous mutation of a human gene. J. Genet. 31:317-326.

7. Wilson, J. M., J. T. Stout, T. D. Palella, B. L. Davidson, W. N. Kelley, and C. T. Caskey. 1986. A molecular survey of hypoxanthineguanine phosphoribosyltransferase deficiency in man. J. Clin. Invest. 77:188-195.

8. Yang, T. P., P. I. Patel, A. C. Chinault, J. T. Stout, L. G. Jackson, B. M. Hildebrand, and C. T. Caskey. 1984. Molecular evidence for new mutation at the HPRT locus in Lesch-Nyhan patients. Nature (Lond.). 310:412-414. 
9. Wilson, J. M., G. E. Tarr, and W. N. Kelley. 1983. Human hypoxanthine-guanine phosphoribosyltransferase: an amino acid substitution in a mutant form of the enzyme isolated from a patient with gout. Proc. Natl. Acad. Sci. USA. 80:870-873.

10. Wilson, J. M., R. Kobayashi, I. H. Fox, and W. N. Kelley. 1983. Human hypoxanthine-guanine phosphoribosyltransferase: molecular abnormality in a mutant form of the enzyme (HPRT Toronto $). J$. Biol. Chem. 258:6458-6460.

11. Wilson, J. M., and W. N. Kelley. 1984. Human hypoxanthineguanine phosphoribosyltransferase: structural alteration in a dysfunctional enzyme variant (HPRT Munich ) isolated from a patient with gout. J. Biol. Chem. 259:27-30.

12. Wilson, J. M., and W. N. Kelley. 1983. Molecular basis of hypoxanthine-guanine phosphoribosyltransferase deficiency in a patient with the Lesch-Nyhan syndrome. J. Clin. Invest. 71:1331-1335.

13. Davidson, B. L., M. Pashmforoush, W. N. Kelley, and T. D. Palella. 1988. Genetic basis of hypoxanthine-guanine phosphoribosyltransferase deficiency in a patient with the Lesch-Nyhan syndrome

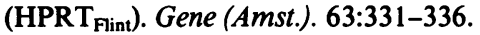

14. Davidson, B. L., T. D. Palella, and W. N. Kelley. 1988. Human hypoxanthine-guanine phosphoribosyltransferase: a single nucleotide substitution in cDNA clones isolated from a patient with Lesch-Nyhan

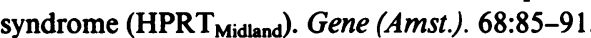

15. Fujimori, S., Y. Hidaka, B. L. Davidson, T. D. Palella, and W. N. Kelley. 1988. Identification of a single nucleotide change in a mutant gene for hypoxanthine-guanine phosphoribosyltransferase (HPRT Ann Arbor $)$ Hum. Genet. 79:39-43.

16. Fujimori, S., B. L. Davidson, W. N. Kelley, and T. D. Palella. 1989. Identification of a single nucleotide change in the hypoxanthine-guanine phosphoribosyltransferase gene $\left(H P R T_{Y_{\text {ale }}}\right)$ responsible for Lesch-Nyhan syndrome. J. Clin. Invest. 83:11-13.

17. Davidson, B. L., S.-C. Chen, J. M. Wilson, W. N. Kelley, and T. D. Palella. 1988. Hypoxanthine-guanine phosphoribosyltransferase. Genetic evidence for identical mutations in two partially deficient subjects. J. Clin. Invest. 82:2164-2167.

18. Davidson, B. L., M. Pashmforoush, W. N. Kelley, and T. D. Palella. 1989. Human hypoxanthine-guanine phosphoribosyltransferase deficiency: the molecular defect in a patient with gout (HPRT Ash- $_{\text {- }}$ ville). J. Biol. Chem. 264:520-525.

19. Yang, T. P., J. T. Stout, D. S. Konecki, P. I. Patel, R. L. Alford, and C. T. Caskey. 1988. Spontaneous reversion of novel Lesch-Nyhan mutation by HPRT gene rearrangement. Somatic Cell Mol. Genet. 14:293-303.

20. Saiki, R. K., D. H. Gelfand, S. Stoffel, S. J. Scharf, R. Higuchi, G. T. Horn, K. B. Mullis, and H. A. Erlich. 1988. Primer-directed enzymatic amplification of DNA with a thermostable DNA polymerase. Science (Wash. DC). 239:487-491.

21. Wilson, J. M., B. W. Baugher, P. M. Mattes, P. E. Daddona, and W. N. Kelley. 1982. Human hypoxanthine-guanine phosphoribosyltransferase. Demonstration of structural variants in lymphoblastoid cells derived from patients with a deficiency of the enzyme. J. Clin. Invest. 69:706-715.

22. Chirgwin, J. M., A. E. Pryzbyla, R. J. MacDonald, and W. J. Rutter. 1979. Isolation of biologically active ribonucleic acid from sources enriched in ribonuclease. Biochemistry. 18:5294-5299.

23. Gubler, U., and B. J. Hoffman. 1983. A simple and very effcient method for generating cDNA libraries. Gene (Amst.). 25:263269.

24. Sanger, F., S. Nicklen, and A. R. Coulson. 1977. DNA sequencing with chain-terminating inhibitors. Proc. Natl. Acad. Sci. USA. 74:5463-5467.

25. Maniatis, T., E. F. Fritsch, and J. Sambrook. 1982. Molecular Cloning: A Laboratory Manual. Cold Spring Harbor Laboratories, Cold Spring Harbor, NY. 125.

26. Engelke, D. R., P. A. Hoener, and F. S. Collins. 1988. Direct sequencing of enzymatically amplified human genomic DNA. Proc. Natl. Acad. Sci. USA. 85:544-548.

27. Holden, J. A., and W. N. Kelley. 1978. Human hypoxanthineguanine phosphoribosyltransferase: evidence for tetrameric structure. J. Biol. Chem. 253:4459-4463.

28. Zannis, V. I., L. J. Gudas, and D. W. Martin, Jr. 1980. Characterization of the subunit composition of HGPRTase from human erythrocytes and cultured fibroblasts. Biochem. Genet. 18:1-19.

29. Wolf, H., S. Madrow, M. Motz, B. Jameson, G. Hermann, and B. Fortsch. 1988. An integrated family of amino acid sequence analysis programs. Comput. Appl. Biosci. 4:187-191.

30. Cariello, N. F., J. K. Scott, A. G. Kat, W. G. Thilly, and P. Keohavong. 1988. Resolution of a missense mutant in human genomic DNA by denaturing gradient gel electrophoresis and direct se-

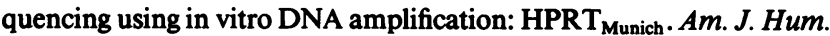
Genet. 42:726-734.

31. Simpson, D., R. M. Crosby, and T. R. Skopek. 1988. A method for specific cloning and sequencing of human HPRT cDNA for mutation analysis. Biochem. Biophys. Res. Commun. 151:487-492.

32. Hershey, H. V., and M. W. Taylor. 1986. Nucleotide sequence and deduced amino acid sequence of Escherichia coli adenine phosphoribosyltransferase and comparison with other analogous enzymes. Gene (Amst.). 43:287-293.

33. Melton, D. W., D. S. Konecki, J. Brennand, and C. T. Caskey. 1984. Structure, expression, and mutation of the hypoxanthine phosphoribosyltransferase gene. Proc. Natl. Acad. Sci. USA. 81:2147-2151.

34. Nishikawa, K. 1983. Assessment of secondary-structure prediction of proteins: comparison of computerized Chou-Fasman method with others. Biochim. Biophys. Acta. 748:285-299.

35. Chou, P. Y., and G. D. Fasman. 1978. Empirical predictions of protein conformation. Annu. Rev. Biochem. 47:251-276. 